\title{
Attitude of Future Doctors Towards Smoking: Are They Really Propagating Ideal Lifestyles?
}

\author{
Mian Muhammad Hassan Ahmed, Shizray Haral, Adeela Komal, Faiza Rameen Shahid, \\ Muhammad Moiz Muzaffar, and Tayyab Mumtaz Khan
}

\section{ABSTRACT}

\begin{abstract}
We conducted this study to assess the attitude and practices of medical students towards tobacco smoking whilst knowing its hazards. This crosssectional study was conducted by inviting students to complete an online anonymous questionnaire to ensure confidential, valid responses from January 2020 to March 2020. All of the MBBS students, from first year to final year, who were studying in that time period were included in this study. All statistical analyses were conducted using IBM SPSS Statistics for Windows, Version 25.0. (Armonk, NY: IBM Corp.). Of the 1700 students, 385 students aged 17 to 26 years (mean age, 21 years) participated in this study. The prevalence of smoking among students was $23.1 \%$. Smoking was significantly related to older age $(p=0.000)$. Total of $137(35.58 \%)$ students were passive smokers whereas $51(13.24 \%)$ students were passive smokers in addition to being active smokers $(\mathbf{P}=\mathbf{0 . 0 0 0})$. The main motives for starting smoking were curiosity $(53.93 \%)$, peer pressure $(41.60 \%)$, and increased concentration $(38.20 \%)$. Most of the students had knowledge of the prominent hazards of tobacco smoking like chronic lung diseases $(95.06 \%)$, cancer in general $(94.02 \%)$, and cardiovascular diseases $(91.16 \%)$ but insufficient knowledge on other hazards. Educational lessons about smoking hazards $(61.8 \%)$, prevention of smoking at universities, schools, and hospitals $(59.0 \%)$, and increasing taxes on cigarettes $(57.1 \%)$ were some suggestions put forward by students to prevent smoking. Smoking cigarettes remains a major threat among medical students. Although the vast majority of students showed a better attitude towards cigarette smoking prevention, they still lack sufficient knowledge about smoking hazards.
\end{abstract}

Keywords: Smoking Prevention, Tobacco Products, Tobacco Smoking, Medical Student, Exploratory Behavior.
Published Online: November 30, 2020

ISSN: $2593-8339$

DOI: $10.24018 /$ ejmed.2020.2.6.576

Mian Muhammad Hassan Ahmed

Rawalpindi Medical University, Pakistan. Shizray Haral

Rawalpindi Medical University, Pakistan. Adeela Komal

Rawalpindi Medical University, Pakistan. Faiza Rameen Shahid

Rawalpindi Medical University, Pakistan. Muhammad Moiz Muzaffar

Rawalpindi Medical University, Pakistan. Tayyab Mumtaz Khan*

Rawalpindi Medical University, Pakistan. (e-mail: tayyab.mkhan98@gmail.com)

*Corresponding Author

\section{INTRODUCTION}

Not only tobacco but non-tobacco consumers are also suffering from tobacco-related illnesses due to passive smoking or coming in contact with spit of oral smokeless tobacco users [1]. It has been labelled for reducing average life expectancy of the people, causing them to die prematurely [2]. It is the leading preventable cause of death and as expressed by World Health Organization's (WHO) latest estimate, by the year 2030, it will cause 10 million deaths worldwide, $70 \%$ being in low and middle-income countries. According to WHO, 1.1 billion that is $1 / 3^{\text {rd }}$ of the global population are smokers, aged 15 and over [3]. Due to public health measures in developed countries, the trend of smoking is either static or declining whereas it is alarmingly increasing in developing countries due to huge advertisement by cigarette firms [3], [4]. According to WHO's latest estimate in $2015,20.2 \%$ of world population aged $\geq 15$ years were current smokers which were $6.7 \%$ less than that recorded in 2000. After that, when FCTC (Framework Convention on Tobacco Control) came into force in 2005, the smoking prevalence reduced by $4.1 \%$ [5].
Smokers are more prone to opportunistic infections because tobacco has made them immunocompromised and has reduced their ability to combat diseases [6]. Also, cigarettes sold in developing countries are not of very good quality. They contain a high proportion of tar and hence are very dangerous to health. Due to this reason, common communicable diseases such as viral flu that gets resolved in a few days in persons with normal immunity gets aggravated in smokers [6], [7].

Pakistan is a heavy tobacco consuming country. According to WHO's 2013 standardized estimate of smoking prevalence, $31.8 \%$ men, $5.8 \%$ women and $19.1 \%$ of Pakistan's adult population consume tobacco in one form or another [8]. Various forms being used are cigarettes, cigars, bidi and huqqa also known as sheesha in upper-class people [9], [10].

Pakistan is among those 15 countries that have tobaccorelated serious health hazards [8]. Due to weak anti-tobacco legislation and lack of awareness among people, tobaccorelated illnesses are expected to increase a lot [9]. It damages almost every organ of the body causing at least 17 different cancers and tobacco alone is responsible for $30 \%$ of all 
cancer-related deaths [11]. The incidence of lung cancer, chronic obstructive pulmonary disease (COPD) and myocardial infarction is increasing with an increase in the sale of cigarettes [12], [13]. Exposure to second-hand smoke is a significant risk factor for lung cancer, COPD, tuberculosis (TB) and asthma. Children start to suffer the impacts of second-hand tobacco exposure before they even learn to walk [14].

There are significant trends of smoking among students of various medical universities despite having profound knowledge about its hazards. General public depends solely on health professionals and consider their advice as the last word. Due to this, medical professionals should be more aware of smoking-related diseases so that they should be able to device a comprehensive plan and prescribe anti-tobacco measures efficiently. This study was also conducted for the same purpose to assess knowledge, attitude and practice of smoking among the medical students of Rawalpindi Medical University (RMU), Rawalpindi, Pakistan.

\section{SUBJECTS AND METHODS}

This descriptive, cross-sectional study was conducted in Rawalpindi Medical University (RMU), using nonprobability convenience sampling in a time frame of three months from January 2020 to March 2020. All of the MBBS students who were studying in that time frame were invited to participate in the study by filling an online anonymous questionnaire in order to ensure confidentiality and valid responses from them. For ethical purposes and to preserve anonymity, names and identification points were not noted. Non-MBBS students and students who were a part of this university but had been passed out were excluded from this study.

The questionnaire was in the English language developed by using Global Tobacco Surveillance System (GTSS) which includes the collection of data through Global Health Professionals Survey (GHPS), and Global Youth Tobacco Survey (GYTS) [15]. The questionnaire comprised of six sections assessing socio-demographic characteristics, smoking habits, attitude, knowledge about tobacco-related diseases, prevention of smoking and source of knowledge. Data was collected after ethical approval from ethical review board, RMU.

Smoking status was defined as former, regular, and occasional cigarette smoking at the time of study, according to WHO criteria [16]. The one who smoked at least one cigarette daily during the last one-month was considered current smoker, the one who smoked at least one cigarette per month but not daily was considered occasional smoker whereas former smokers were those who quit smoking but previously smoked at least one cigarette a day. Non-smokers were those who never smoked. Active smokers were considered those who voluntarily smoke whereas passive smokers referred to those who involuntarily inhale smoke from cigarettes or other tobacco products smoked by other people.

Data entry and analysis were done using IBM SPSS, Statistics for Windows, Version 25.0. (Armonk, NY: IBM Corp.). Frequencies and numbers for categorical variables were calculated using descriptive analysis while mean and standard deviation (S.D.) were calculated for continuous variables. Prevalence of smoking between different groups of students was measured using Pearson's Chi-square test. A P value of less than 0.05 was considered significant statistically.

\section{RESULTS}

A total of 385 students, aged 17-26 years (mean age, 21years), from first to final year MBBS students, participated in this study. Of which $202(52.46 \%)$ were females and 183 $(47.53 \%)$ were males. The prevalence of smoking was found to be $23.1 \%$. We didn't find any female smoker in our research. It was found that $76(85.39 \%)$ smokers belong to the urban area and $50(56.17 \%)$ smokers had a family income higher than $1,00,000(\mathrm{P}=0.05)$ (see Table 1).

Smoking was significantly related to higher age of students (mean age, 22.54 versus 20.54 of non-smokers) and among senior classes $(\mathrm{P}=0.000)$. $15-18$ years was found to be the commonest age group for starting smoking while most of the smokers had been found to be smoking from last one to four years (see Table 2).

Friends had a great influence on initiation of smoking in $52.80 \%$ smokers. There were $42.69 \%$ smokers who preferred to smoke outdoors, while $44.94 \%$ smokers smoked at more than one place as described in Table 3 .

Total of $137(35.58 \%)$ students were passive smokers whereas $51(13.24 \%)$ students were passive smokers in addition to being active smokers $(\mathrm{P}=0.000)$. The prevalence of smoking among the student's families was $36.62 \%$ with fathers being the most common smokers as depicted in Table 4.

$72(80.89 \%)$ smokers wished to stop smoking. Of which, $18(25.0 \%)$ said that they wanted to quit smoking but need help. Another $30(41.67 \%)$ smokers said that they tried to quit smoking and were successful to some extent. But 24 $(33.33 \%)$ smokers tried to quit smoking but were unsuccessful to do so. Curiosity was the main motive in $53.93 \%$ smokers. Regarding the ethics of smoking, almost all smokers said that smoking is forbidden in general places and public transport as clear from Table 5.

Table 6 revealed that majority of the students, regardless of their cigarette smoking behavior, had good knowledge about its impact on health like cardiovascular disease, chronic lung diseases and increased mortality. But a large number of students were still unaware of the consequences of smoking.

Some of the suggestions made by students to prevent smoking include giving educational lessons about smoking hazards $(61.8 \%)$, prevention of smoking at university, schools and hospitals (59.0\%), and increasing taxes on cigarettes $(57.1 \%)$ (see Table 7 )

Radio/ television $(63.9 \%)$, books and magazines $(61.0 \%)$, and schools $(54.5 \%)$ were some of the primary means of getting information about smoking hazards (see Table 8). 
TABLE 1: CHARACTERISTICS OF PARTICIPANTS

\begin{tabular}{|c|c|c|c|c|c|c|c|}
\hline \multicolumn{2}{|c|}{ Characteristic } & Non-Smoker & $\begin{array}{l}\text { Current } \\
\text { Smoker }\end{array}$ & $\begin{array}{l}\text { Occasional } \\
\text { Smoker }\end{array}$ & Ex-Smoker & Total & P Value \\
\hline \multirow{4}{*}{ Age } & $15-18$ years & 35 & 0 & 0 & 3 & 38 & \multirow{4}{*}{$\mathrm{P}=0.000$} \\
\hline & $19-22$ years & 232 & 27 & 8 & 5 & 272 & \\
\hline & $>23$ years & 29 & 32 & 6 & 8 & 75 & \\
\hline & Mean \pm S. D & $20.54+1.626$ & $22.75+1.657$ & $22.50 \pm 1.160$ & $21.81 \pm 2.105$ & $21 \pm 1.846$ & \\
\hline \multirow{2}{*}{ Gender } & Female & 202 & 0 & 0 & 0 & 202 & \multirow{3}{*}{$\mathrm{P}=0.000$} \\
\hline & Male & 94 & 59 & 14 & 16 & 183 & \\
\hline \multirow{5}{*}{$\begin{array}{c}\text { Year of } \\
\text { studying }\end{array}$} & $1^{\text {st }}$ Year & 86 & 0 & 0 & 3 & 89 & \\
\hline & $2^{\text {nd }}$ Year & 46 & 3 & 0 & 0 & 49 & \multirow{4}{*}{$\mathrm{P}=0.000$} \\
\hline & $3^{\text {rd }}$ Year & 35 & 15 & 3 & 0 & 53 & \\
\hline & $4^{\text {th }}$ Year & 102 & 12 & 8 & 7 & 129 & \\
\hline & $5^{\text {th }}$ Year & 27 & 29 & 3 & 6 & 65 & \\
\hline \multirow{3}{*}{$\begin{array}{l}\text { Family } \\
\text { Income }\end{array}$} & $<20,000$ & 19 & 1 & 6 & 0 & 26 & \multirow{3}{*}{$\mathrm{P}=0.000$} \\
\hline & $\begin{array}{l}20,000- \\
1,00,000\end{array}$ & 145 & 26 & 0 & 6 & 177 & \\
\hline & $>1,00,000$ & 132 & 32 & 8 & 10 & 182 & \\
\hline \multirow{2}{*}{ Address } & Urban & 264 & 52 & 8 & 16 & 340 & \multirow{2}{*}{$\mathrm{P}=0.001$} \\
\hline & Rural & 32 & 7 & 6 & 0 & 45 & \\
\hline
\end{tabular}

${ }^{*} p<0.05$, statistically significant; $p>0.05$, non-significant.

TABLE 2: CHARACTERISTICS OF SMOKERS

\begin{tabular}{|c|c|c|c|c|c|}
\hline Characteristic & Current Smoker & $\begin{array}{l}\text { Occasional } \\
\text { Smoker }\end{array}$ & Ex-Smoker & Total & P Value \\
\hline \multicolumn{6}{|c|}{ Age at start of smoking } \\
\hline - $15-18$ years & $29(32.58 \%)$ & $3(3.37 \%)$ & $13(14.60 \%)$ & $45(50.56 \%)$ & \multirow[b]{3}{*}{$\mathrm{P}=0.01$} \\
\hline - 19-22 years & $27(30.33 \%)$ & $11(12.35 \%)$ & $3(3.37 \%)$ & $41(46.06 \%)$ & \\
\hline - $\quad>23$ years & $3(3.37 \%)$ & $0(0.00 \%)$ & $0(0.00 \%)$ & $3(3.37 \%)$ & \\
\hline Mean \pm S. D & $18.68+2.345$ & $19.14 \pm 2.507$ & $17.81 \pm 1.276$ & $18.60 \pm 2.235$ & - \\
\hline \multicolumn{6}{|l|}{$\begin{array}{l}\text { Age at which did they } \\
\text { quit smoking }\end{array}$} \\
\hline - $15-18$ years & 0 & 0 & $5(31.25 \%)$ & $5(31.25 \%)$ & \multirow{3}{*}{-} \\
\hline - 19-22 years & 0 & 0 & $11(68.75 \%)$ & $11(68.75 \%)$ & \\
\hline - $\quad>23$ years & 0 & 0 & 0 & 0 & \\
\hline \multicolumn{6}{|l|}{$\begin{array}{l}\text { Number of } \\
\text { cigarettes/day }\end{array}$} \\
\hline - $<5$ & $18(20.22 \%)$ & $12(13.48 \%)$ & $11(12.35 \%)$ & $41(46.06 \%)$ & \multirow{4}{*}{$\mathrm{P}=0.003$} \\
\hline - $5-10$ & $10(11.23 \%)$ & $2(2.24 \%)$ & $2(2.24 \%)$ & $14(15.73 \%)$ & \\
\hline - $11-20$ & $27(30.33 \%)$ & 0 & $3(3.37 \%)$ & $30(33.70 \%)$ & \\
\hline - $>1$ pack & $4(4.49 \%)$ & 0 & 0 & $4(4.49 \%)$ & \\
\hline \multicolumn{6}{|l|}{ Duration of smoking } \\
\hline - 1-4 years & $37(41.57 \%)$ & $11(12.35 \%)$ & $13(14.6 \%)$ & $61(68.53 \%)$ & \multirow{3}{*}{$\mathrm{P}=0.482$} \\
\hline - 5-8 years & $19(21.34 \%)$ & $3(3.37 \%)$ & $3(3.37 \%)$ & $25(28.08 \%)$ & \\
\hline - $\quad>8$ years & $3(3.37 \%)$ & 0 & 0 & $3(3.37 \%)$ & \\
\hline
\end{tabular}

${ }^{*} p<0.05$, statistically significant; $p>0.05$, non-significant

TABLE 3: SOURCE of First Cigarette AND Most Common Place of

\begin{tabular}{ccc}
\multicolumn{4}{c}{ SMOKING } \\
\hline Characteristic & Frequency & Percentage \\
\hline Source of $1^{\text {st }}$ cigarette & & \\
$\bullet \quad$ Friends & 47 & $52.80 \%$ \\
- $\quad$ Family & 12 & $13.48 \%$ \\
- $\quad$ Cafe & 8 & $8.98 \%$ \\
- Neighbors & 5 & $5.61 \%$ \\
Oost common place of smoking & 17 & $19.10 \%$ \\
- Outdoors & 38 & \\
- At home & 3 & $32.69 \%$ \\
- At café & 5 & $5.37 \%$ \\
- At means of transportation & 3 & $3.37 \%$ \\
- More than one place & 40 & $44.94 \%$ \\
\hline
\end{tabular}

TABLE 4: RELATIONSHIP B/W SMOKING AMONG STUDENTS AND FAMILY

\begin{tabular}{lcccc}
\multicolumn{5}{c}{ MEMBERS } \\
\hline Characteristics & Smoker & Non-smoker & Total & P-value \\
\hline Passive smoking & $51(13.24 \%)$ & $86(22.33 \%)$ & $137(35.58 \%)$ & $\mathrm{P}=0.000$ \\
$\begin{array}{l}\text { Smoking among } \\
\text { other family }\end{array}$ & & & & \\
$\quad$ members & $37(41.57 \%)$ & $104(35.13 \%)$ & $141(36.62 \%)$ & \\
- $\quad$ Yes & $52(58.42 \%)$ & $192(64.86 \%)$ & $244(63.37 \%)$ & \\
- $\quad$ No & & & & \\
Who is smoker & & & & \\
among other family & & & & \\
$\quad$ members? & & & \\
- Father & $10(27.02 \%)$ & $42(40.38 \%)$ & $52(36.87 \%)$ & \\
- $\quad$ Brother & $22(59.46 \%)$ & $19(18.26 \%)$ & $41(29.07 \%)$ & \\
- Grandfather & $2(5.41 \%)$ & $10(9.62 \%)$ & $12(8.51 \%)$ & $\mathrm{P}=0.000$ \\
- $\quad$ Others & $3(8.11 \%)$ & $33(31.73 \%)$ & $36(25.53 \%)$ & \\
$\quad$ Total & $37(41.57 \%)$ & $104(35.13 \%)$ & $141(100.00 \%)$ & - \\
\hline
\end{tabular}

${ }^{*} p<0.05$, statistically significant; $p>0.05$, non-significant 
TABLE 6: KNOWLEDGE ABOUT TOBACCO RELATED DISEASES

\begin{tabular}{|c|c|c|c|c|}
\hline \multirow{2}{*}{ Knowledge } & \multicolumn{2}{|c|}{ Smoking Status } & \multirow{2}{*}{ Total } & \multirow{2}{*}{ P Value } \\
\hline & Smoker & Non-Smoker & & \\
\hline \multicolumn{5}{|l|}{ Hazardous effect on health } \\
\hline - Yes & $82(92.13 \%)$ & $285(96.28 \%)$ & $367(95.32 \%)$ & \multirow{3}{*}{$\mathrm{P}=0.102$} \\
\hline - No & $7(7.86 \%)$ & $9(3.04 \%)$ & $16(4.15 \%)$ & \\
\hline - Don't know & $0(0.00 \%)$ & $2(0.67 \%)$ & $2(0.52 \%)$ & \\
\hline \multicolumn{5}{|l|}{ Risk for cancer in general } \\
\hline - Yes & $79(88.76 \%)$ & $283(95.60 \%)$ & $362(94.02 \%)$ & \multirow{3}{*}{$\mathrm{P}=0.00$} \\
\hline - No & $10(11.23 \%)$ & $9(3.04 \%)$ & $19(4.93 \%)$ & \\
\hline - Don't know & $0(0.00 \%)$ & $4(1.35 \%)$ & $4(1.03 \%)$ & \\
\hline \multicolumn{5}{|c|}{ Risk for cancer in genitourinary tract } \\
\hline - Yes & $63(70.78 \%)$ & $126(42.56 \%)$ & $189(49.09 \%)$ & \multirow{3}{*}{$\mathrm{P}=0.000$} \\
\hline • No & $13(14.60 \%)$ & $54(18.24 \%)$ & $67(17.40 \%)$ & \\
\hline - Don't know & $13(14.60 \%)$ & $116(39.18 \%)$ & $129(33.50 \%)$ & \\
\hline \multicolumn{5}{|l|}{ Risk for CVS disease } \\
\hline - Yes & $79(88.76 \%)$ & $272(91.89 \%)$ & $351(91.16 \%)$ & \multirow{3}{*}{$\mathrm{P}=0.17$} \\
\hline - No & $7(7.86 \%)$ & $10(3.37 \%)$ & $17(4.41 \%)$ & \\
\hline - Don't know & $3(3.37 \%)$ & $14(4.73 \%)$ & $17(4.41 \%)$ & \\
\hline \multicolumn{5}{|c|}{ Risk for chronic lung diseases } \\
\hline - Yes & $78(87.64 \%)$ & $288(97.29 \%)$ & $366(95.06 \%)$ & \multirow{3}{*}{$\mathrm{P}=0.000$} \\
\hline - No & $7(7.86 \%)$ & $7(2.36 \%)$ & $14(3.63 \%)$ & \\
\hline - Don't know & $4(4.49 \%)$ & $1(0.33 \%)$ & $5(1.29 \%)$ & \\
\hline \multicolumn{5}{|c|}{ Risk of congenital anomalies of } \\
\hline - Yes & $72(80.89 \%)$ & $210(70.94 \%)$ & $282(73.24 \%)$ & \multirow{3}{*}{$\mathrm{P}=0.177$} \\
\hline $\begin{array}{l}- \text { yes } \\
-\mathrm{No}\end{array}$ & $7(7.86 \%)$ & $35(11.82 \%)$ & $42(10.90 \%)$ & \\
\hline $\begin{array}{l}\text { - No } \\
\text { - Don't know }\end{array}$ & $10(11.23 \%)$ & $51(17.22 \%)$ & $61(15.84 \%)$ & \\
\hline Risk for infertility & & & & \\
\hline - Yes & $56(62.92 \%)$ & $143(48.31 \%)$ & $199(51.68 \%)$ & \\
\hline - No & $22(24.71 \%)$ & $43(14.52 \%)$ & $65(16.88 \%)$ & $\mathrm{P}=0.000$ \\
\hline - Don't know & $11(12.35 \%)$ & $110(37.16 \%)$ & $121(31.42 \%)$ & \\
\hline Risk for weak sex & & & & \\
\hline - Yes & $57(64.04 \%)$ & $119(40.20 \%)$ & $176(45.71 \%)$ & \\
\hline - No & $17(19.10 \%)$ & $41(13.85 \%)$ & $58(15.06 \%)$ & $\mathrm{P}=0.000$ \\
\hline - Don't know & $15(16.85 \%)$ & $136(45.94 \%)$ & $151(39.22 \%)$ & \\
\hline Risk for osteomalacia & & & & \\
\hline - Yes & $55(61.79 \%)$ & $111(37.50 \%)$ & $166(43.11 \%)$ & \\
\hline - No & $16(17.97 \%)$ & $39(13.17 \%)$ & $55(14.28 \%)$ & $\mathrm{P}=0.000$ \\
\hline - Don't know & $18(20.22 \%)$ & $146(49.32 \%)$ & $164(42.59 \%)$ & \\
\hline Cause of addiction & & & & \\
\hline - Yes & $85(95.50 \%)$ & $265(89.53 \%)$ & $350(90.90 \%)$ & \\
\hline - No & $4(4.49 \%)$ & $10(3.37 \%)$ & $14(3.63 \%)$ & $\mathrm{P}=0.03$ \\
\hline - Don't know & $0(0.00 \%)$ & $21(7.09 \%)$ & $21(5.45 \%)$ & \\
\hline Risk for insomnia and fatig & & & & \\
\hline - Yes & $60(67.41 \%)$ & $220(74.32 \%)$ & $280(72.72 \%)$ & \\
\hline - No & $27(30.33 \%)$ & $33(11.14 \%)$ & $60(15.58 \%)$ & \\
\hline - Don't know & $2(2.24 \%)$ & $43(14.52 \%)$ & $45(11.68 \%)$ & $\mathrm{P}=0.000$ \\
\hline Risk of increased appetite & & & & \\
\hline garn & $41(46.06 \%)$ & $111(37.50 \%)$ & $152(39.48 \%)$ & \\
\hline - Yes & $39(43.82 \%)$ & $80(27.02 \%)$ & $119(30.90 \%)$ & $\mathrm{P}=0.000$ \\
\hline $\begin{array}{l}\text { - No } \\
\text { - Don't know }\end{array}$ & $9(10.11 \%)$ & $105(35.47 \%)$ & $114(29.61 \%)$ & \\
\hline Risk for increased mortalit & & & & \\
\hline - Yes & $63(70.78 \%)$ & $263(88.85 \%)$ & $326(84.67 \%)$ & \\
\hline - No & $18(20.22 \%)$ & $19(6.42 \%)$ & $37(9.61 \%)$ & $\mathrm{D}-\mathrm{\rho} \rho 0 \Omega$ \\
\hline - Don't know & $8(8.98 \%)$ & $14(4.72 \%)$ & $22(5.71 \%)$ & $\mathrm{P}=0.000$ \\
\hline Cause of increased activity & & & & \\
\hline - Yes & $64(71.91 \%)$ & $103(34.79 \%)$ & $167(43.37 \%)$ & \\
\hline - No & $19(21.34 \%)$ & $110(37.16)$ & $129(33.50 \%)$ & $\mathrm{P}=0.000$ \\
\hline - Don't know & $6(6.74 \%)$ & $83(28.04 \%)$ & $89(23.11 \%)$ & \\
\hline Cause of increased concent & & & & \\
\hline - Yes & $62(69.66 \%)$ & $110(37.16 \%)$ & $172(44.67 \%)$ & \\
\hline - No & $23(25.84 \%)$ & $104(35.13 \%)$ & $127(32.98 \%)$ & $\mathrm{P}=0.000$ \\
\hline - Don't know & $4(4.49)$ & $82(27.70 \%)$ & $86(22.33 \%)$ & \\
\hline
\end{tabular}

$* p<0.05$, statistically significant; $p>0.05$, non-significant. 
TABLE 5: ATTITUDE OF SMOKERS TOWARDS SMOKING

\begin{tabular}{|c|c|c|}
\hline Attitude & Yes & No \\
\hline $\begin{array}{l}\text { Do you think that smoking } \\
\text { has problem solving effect }\end{array}$ & $44(49.43 \%)$ & $45(50.57 \%)$ \\
\hline Do you want to stop smoking & $72(80.89 \%)$ & $17(19.10 \%)$ \\
\hline $\begin{array}{l}\text { Do you smoke in closed } \\
\text { places }\end{array}$ & $55(61.79 \%)$ & $34(38.21 \%)$ \\
\hline $\begin{array}{l}\text { Do you know that smoking is } \\
\text { prevented in closed places }\end{array}$ & $53(59.55 \%)$ & $36(40.44 \%)$ \\
\hline $\begin{array}{l}\text { Motives for smoking } \\
\text { - Curiosity }\end{array}$ & & \\
\hline - $\quad$ Peer pressure & $48(53.93 \%)$ & $41(46.06 \%)$ \\
\hline - $\quad$ Acquired habits from & $37(41.60 \%)$ & $52(58.40 \%)$ \\
\hline parents or relatives & $17(19.10 \%)$ & $72(80.89 \%)$ \\
\hline - Makes one look mature & $13(14.60 \%)$ & $76(85.39 \%)$ \\
\hline $\begin{array}{ll}\text { (sign of maturity) } \\
\text { - Sign of welfare }\end{array}$ & $5(5.61 \%)$ & $84(94.38 \%)$ \\
\hline Not forbidden from religion & $16(17.97 \%)$ & $73(82.02 \%)$ \\
\hline Increased body activities & $13(14.60 \%)$ & $76(85.39 \%)$ \\
\hline Increased concentration & $34(38.20 \%)$ & $55(61.79 \%)$ \\
\hline $\begin{array}{l}\text { Smoking is not prevented in } \\
\text { general places and means of } \\
\text { transportation }\end{array}$ & $9(10.11 \%)$ & $80(89.88 \%)$ \\
\hline
\end{tabular}

TABLE 7: SUGGESTIONS FOR PREVENTION OF SMOKING

\begin{tabular}{ccc}
\hline Suggestions & Yes & No \\
\hline $\begin{array}{c}\text { Fee for smoking at public places and } \\
\text { means of transportation }\end{array}$ & $137(35.6 \%)$ & $248(64.4 \%)$ \\
$\begin{array}{c}\text { Smokers at public places should be } \\
\text { isolated at special sites }\end{array}$ & $141(36.6 \%)$ & $244(63.4 \%)$ \\
$\begin{array}{c}\text { Prevention of smoking at universities, } \\
\text { schools and hospitals }\end{array}$ & $227(59.0 \%)$ & $158(41.0 \%)$ \\
$\quad \begin{array}{c}\text { Increased taxes on cigarettes } \\
\text { Prevention of cigarette import and } \\
\text { advertisement }\end{array}$ & $220(57.1 \%)$ & $165(42.9 \%)$ \\
$\quad \begin{array}{c}\text { Smokers are not allowed to act as } \\
\text { community leaders or top occupation }\end{array}$ & $60(15.6 \%)$ & $325(84.4 \%)$ \\
$\begin{array}{c}\text { Do not sit beside smokers during smoking } \\
\text { Do not allow smoking during home visits }\end{array}$ & $137(35.6 \%)$ & $248(64.4 \%)$ \\
Educational lessons about smoking & $238(61.8 \%)$ & $147(38.2 \%)$ \\
\hline hazards & $201(52.2 \%)$ \\
\hline
\end{tabular}

TABLE 8: SOURCE OF KNOWLEDGE ABOUT SMOKING HAZARDS:

\begin{tabular}{ccc}
\hline Source & Yes & No \\
\hline Radio/TV & $246(63.9 \%)$ & $139(36.1 \%)$ \\
Books/magazines & $235(61.0 \%)$ & $150(39.0 \%)$ \\
Session about & $161(41.8 \%)$ & $224(58.2 \%)$ \\
smoking & & \\
Family & $176(45.7 \%)$ & $209(54.3 \%)$ \\
Schools & $210(54.5 \%)$ & $175(45.5 \%)$ \\
\hline
\end{tabular}

\section{DISCUSSION}

Health professionals being the key influencers, play a major role in combating smoking within a community. They can also have an impact on future policies and practices that is why their awareness, point of view and execution towards tobacco use was the principal focus of this survey. The reliability and integrity of anti-smoking messages to people is lost if medical students themselves are indulged in this activity.

Although medical professionals smoke less than the general population yet, the prevalence of smoking among medical students is still alarmingly high which have been shown by various studies [17]-[20]. This sets a poor example to their patients [4], [21]. Prevalence of smoking in our study was found to be $23.1 \%$, very close to prevalence of $24 \%$ in a study conducted in same university in 2013 [22]. But studies done at Allama Iqbal Medical University, Lahore and University of Azad Jammu and Kashmir, Pakistan showed much higher prevalence of $47.3 \%$ and $49.5 \%$ respectively [18], [19]. Another study conducted in the same city, Rawalpindi showed $32.1 \%$ prevalence while a study in Agha Khan University, Karachi showed prevalence of $14.4 \%$ [23], [24]. Luckily, we did not find any female smoker in our study. Moreover, a study conducted among medical students of Riyadh, Saudi Arabia also did not show any prevalence among female students [25].

Many factors had been found to be responsible for smoking initiation but most common were curiosity $(53.93 \%)$ and peer pressure $(41.60 \%)$. Source of the first cigarette was usually friends $(52.80 \%)$, second being the family (13.48\%). Similar results were shown by studies conducted in Pakistan and Saudi Arabia [9], [19], [25]. Family history of smoking plays a significant role in initiation of smoking. It might not be the premium cause, but it did influence the smoking habits as per stated by smokers. This point was documented by some other researchers also [17], [18]. The number of cigarettes varied among smokers, most of them smoked fewer than 5 cigarettes and a little percentage smoked more than 1 pack per day. It was similar to the results obtained in studies done at Khyber Medical College, Peshawar and Ziauddin Medical University, Karachi, Pakistan [17], [26].

Our study showed that regardless of their cigarette smoking behavior, majority of the students had good knowledge about its consequences on health. Unfortunately, adequate knowledge about smoking was still lacking in large number of students. And not only in Pakistan, but studies done in other countries had also shown similar results i.e., lack of adequate knowledge. Hence, educating students about the hazards of smoking should be emphasized. Students knew a lot about cancer and chronic lung diseases being the hazards of smoking followed by knowledge of heart diseases just because of good advertisement of these smoking-related health issues [25], [26]. This shows that medical students were aware of some, if not all the hazards of smoking owing to ongoing anti-smoking campaign.

Around $80.89 \%$ of smokers had desired to quit smoking which was correlated with studies carried out in different regions of Pakistan and abroad [17], [19], [27]. This showed that anti-smoking programs might be useful, and if correctly developed in universities, many smokers could respond to it. Therefore, special training is required by all health professionals and medical students to help them quit smoking.

This survey was based on self-reporting which may be biased because of the possibility of underreporting. Also, smoking prevalence among senior students was found to be higher which made us think that other factors might be more influential than mere knowledge about smoking hazards. The study showed that external influences were also one of the major determinants for smoking initiation. This study extended prior knowledge about the prevalence of smoking among medical students but more studies on smoking risk factors will 
help us better comprehend the complex etiology of smoking in medical students.

\section{CONCLUSION}

Smoking is tied to stress, and is not surprising to find in students, however, what is surprising is the degree of smoking found in medical students. Though the vast majority of students had better attitudes towards prevention of cigarette smoking, yet they still lack sufficient knowledge on smoking risks. Therefore, all health professionals and medical students should be prepared to guide their patients about smoking hazards and should be trained to make them quit smoking.

\section{REFERENCES}

[1] World Health Organization. WHO global report: mortality attributable to tobacco. Available from: https://www.who.int/tobacco/publications/surveillance/rep_mortality_a ttributable/en/.

[2] West R. Tobacco smoking: Health impact, prevalence, correlates and interventions. Psychology \& health 2017;32(8):1018-1036.

[3] WHO|. Tobacco [Internet]. Who.int. Available from: https://www.who.int/substance_abuse/facts/tobacco/en/.

[4] Abdulateef DS, Ali AJ, Abdulateef DS, Mohesh MIG. Smoking Knowledge, Attitude, and Practices among Health Care Professionals from Sulaymaniyah City/Iraq. 2016;9:TUI.S38171.

[5] Organization WH. WHO global report on trends in prevalence of tobacco smoking 2000-2025. 2018.

[6] Shah N, Siddiqui S. An overview of smoking practices in Pakistan. Pakistan journal of medical sciences 2015;31(2):467-470.

[7] Wong CM, Yang L, Chan KP, Chan WM, Song L, Lai HK, et al. Cigarette smoking as a risk factor for influenza-associated mortality: evidence from an elderly cohort. Influenza and other respiratory viruses 2013;7(4):531-539.

[8] Organization WWH. Tobacco control in Pakistan. Available from: https://www.who.int/tobacco/about/partners/bloomberg/pak/en/.

[9] Karamat A, Arif N, Malik AK, Chaudhry A, Cheema MA, Rauf AJJTJotPMA. Cigarette smoking and medical students at King Edward Medical University, Lahore (Pakistan). 2011;61(5):509-512.

[10] Kasza KA, Ambrose BK, Conway KP, Borek N, Taylor K, Goniewicz ML, et al. Tobacco-product use by adults and youths in the United States in 2013 and 2014. 2017;376(4):342-353.

[11] Alexandrov LB, Ju YS, Haase K, Van Loo P, Martincorena I, Nik-Zainal $\mathrm{S}$, et al. Mutational signatures associated with tobacco smoking in human cancer. 2016;354(6312):618-622.

[12] O'Keeffe LM, Taylor G, Huxley RR, Mitchell P, Woodward M, Peters SAE. Smoking as a risk factor for lung cancer in women and men: a systematic review and meta-analysis. BMJ open 2018;8(10):e21611e021611.

[13] Haig C, Carrick D, Carberry J, Mangion K, Maznyczka A, Wetherall K, et al. Current Smoking and Prognosis After Acute ST-Segment Elevation Myocardial Infarction: New Pathophysiological Insights. 2018.

[14] Office on S, Health. Publications and Reports of the Surgeon General. The Health Consequences of Involuntary Exposure to Tobacco Smoke: A Report of the Surgeon General. Atlanta (GA): Centers for Disease Control and Prevention (US); 2006.

[15] Warren CW, Lee J, Lea V, Goding A, O'hara B, Carlberg M, et al. Evolution of the Global Tobacco Surveillance System (GTSS) 19982008. 2009;16(2_suppl):4-37.

[16] Organization WH. Guidelines for controlling and monitoring the tobacco epidemic. 1998.

[17] Naeem M, Khan S, Abbas SH, Khan A, Islam Mzujjoms. Knowledge, Attitude and Practice of Tobacco Smoking Among Medical Students In Khyber Pakhtunkhwa. 2018;26(1):3-8.
[18] Mehmood A, Sarwar U, Ahmed W, Tahir H. Knowledge and practices among male medical students regarding smoking and its hazards. 2017 2017;4(8):7 \%J International Journal of Research in Medical Sciences.

[19] Latif Z, Jamshed J, Khan MM. Knowledge, attitude and practice of cigarette smoking among university students in Muzaffarabad, Pakistan: a cross-sectional study. 2017 2017;3(9):7 \%J International Journal of Scientific Reports.

[20] Boopathirajan R, Muthunarayanan L. Awareness, Attitude and Use of Tobacco among Medical Students in Chennai. Journal of lifestyle medicine 2017;7(1):27-34.

[21] Willaing I, Ladelund SJN, research t. Smoking behavior among hospital staff still influences attitudes and counseling on smoking. 2004;6(2):369-375.

[22] Ali IS YN, Fatima G, Iftekhar H, Abbas M. Pattern of Smoking in Medical Students. J Rawalpindi Med Coll. 2013;17(1):140-143.

[23] Mumtaz B, Chaudhary IA, Arshad M, Samiullah. Comparison of smoking behaviour among medical and other college students in Rawalpindi. J Coll Physicians Surg Pak 2009;19(1):7-10.

[24] Khan FM, Husain SJ, Laeeq A, Awais A, Hussain SF, Khan JA. Smoking prevalence, knowledge and attitudes among medical students in Karachi, Pakistan. East Mediterr Health J 2005;11(5-6):952-958.

[25] Al-Haqwi AI, Tamim H, Asery A. Knowledge, attitude and practice of tobacco smoking by medical students in Riyadh, Saudi Arabia. Annals of thoracic medicine 2010;5(3):145-148.

[26] Omair A, Kazmi T, Alam SE. Smoking prevalence and awareness about tobacco related diseases among medical students of Ziauddin Medical University. J Pak Med Assoc 2002;52(9):389-392.

[27] Jamal A, Homa DM, O'Connor E, Babb SD, Caraballo RS, Singh T, et al. Current Cigarette Smoking Among Adults - United States, 20052014. Morbidity and Mortality Weekly Report 2015;64(44):1233-1240.

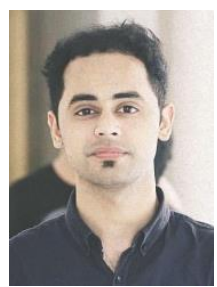

Tayyab Mumtaz Khan

Place and Date of Birth: Lahore, 23-03-1996.

Educational Background: Final year MBBS Student at

Rawalpindi Medical University,Rawalpindi, Pakistan. 